\title{
BUSINESS COOPERATION BETWEEN INDONESIA AND VIETNAM
}

\author{
Nguyen Duc Ngoc \\ Hong Bang International University, Vietnam \\ ngngoc0707@gmail.com
}

\begin{abstract}
Currently, Indonesia has the fourth largest population in the world, with the tenth largest economy by purchasing power, and Indonesia is part of the G-20. Indonesia has an economic long-term developmentto be implemented between 2005 and 2025. The plan is divided into five-year period, each of them with a different sector development priorities. Regarding business climate, although generally positive, Indonesia still continues to experience challenges of uncertainty and lack of infrastructures. However, the Investment Coordinating Board has established one service called Pelayanan Terpadu Satu Pintu (PTSP) that provides business licenses, and there are further regulation for more openness regarding businesses implementations. Vietnam on the other hand has a development success story.The political and economic reform named (Doi Moi) was launched in 1986 and has transformed the country from one of the world's poorest countries, with a per capita income of about $\$ 100$, to a medium income country in a century, with revenues of more than $\$ 2,000$ per capita by the end of 2014. the government has recently paid increasing attention to improve the business environment, with two resolutions that was published in March 2014 and March 2015, established concrete measures to remove obstacles to business creation in Vietnam, with the goal of achieving a business environment comparable to the average of the ASEAN-6 countries group. Both of these countries: Indonesia and Vietnam have been running back ever ties relations, they have now become a means of fostering mutual understanding and strengthened cooperation between them, which is carried on in various sectors of thei reconomy. This paper will discuss about the business relationship between the Republic of Indonesia at the Socialist Republic of Vietnam.
\end{abstract}

\section{Keywords: Business Relations, Economics, Trade, Indonesia, Vietnam}

\section{Introduction}

In the middle of the current global economic slow recovery, during the first five months of 2015, the Vietnamese Government issued important decisions which serve as a guide for the ministers and lower level responsible. Accomplishments such as maintaining a macroeconomic stability, Vietnam has reached a level of growth that is higher than expected. During the first quarter of 2015, the GDP reached 6.03 percent, topping forecasts and 5.06 percent higher than 2014 GDP, the lowest inflation over the years $(0,04$ percent in the first four months of 2015); satisfactory export growth with 50.1 billion US dollars (8.2 percent).

The money market of the country was stable, as indicated by the liquidity of the banking system, the interest rates and loans decreased which allows firms to expand production, credit growth in the first four months of 2015 and reached 2.78 percent, the highest level of the last three years. The market is also slowly recovering. The stock market is becoming more attractive, developing real estate market, the volume of transactions in Hanoi and Ho Chi Minh City increased three times more than the level that was achieved during the same period during 2014. 
What was achieved by Vietnam during that period received appreciation from experts and various institutions such as the World Bank, IMF, ADB and HSBC and foster confidence in the bright prospects for the country's economy in the future.

The Vietnamese economy in a short period of time continue to be stable and grow as governments struggle to overcome numerous barriers that still exist and to restructure the economy in order to develop sustainability for the long term. Financial organizations such as the WB, IMF, ADB and Vietnam HSBC forecast GDP growth in 2015 was 6 percent in 2016 (6.2 percent) and 2017 (6.5 percent). Vietnam's promising economy didn't leave Indonesia indifferent, Indonesia could take advantage of business opportunities that exist for example in the seafood trade sector and Vietnam wants to increase imports of fishery products from Indonesia.

Today, Indonesia as a trading partner of magnitude 4 for Vietnam in Southeast Asia. The value of bilateral trade between the two countries has increased steadily every year, from USD 2.5 billion in 2008 to USD 4.6 billion in 2012. Herrera Hotma, Indonesian economist in 2013 has said: "For 2013, within the creasing trend of trade volume between the two countries, it appears that we are optimistic and we hope that the trade volume between the two countries can exceed the volume of trade in 2012, and increased in 2015 USD to 5 billions1.Indonesia currently occupies the 27 th position among 101 countries that invest in Vietnam with 35 projects that are still running and with a total registered capital of approximately USD 285 million. Now, Indonesia has invested in 11 among all 21 fields, of which there are areas of processing and manufacturing industries in the first position with 16 projects and a total registered capital of approximately USD 112.17 million, occupying $39.34 \%$ of total capital investment 2 .

Several types of commodities are subject to export from Indonesia by Vietnam, steel, machinery and production materials, chemicals, automobile pieces, computer piece, fertilizers and pharmaceutical products. Meanwhile, Indonesia imported from Vietnam several types of commodities such as crude oil, rice, tea, and coffee. Vietnam and Indonesia still have the potential to be complementary to each other in the field of energy and food. Vietnam wants to import coal from the long-term and stabilize Indonesia for thermoelectric plants. Meanwhile, Vietnam ensures a stable supply of resources to the needs of Indonesia's regarding rice. To boost economic ties between the two countries, from the beginning of 2013, they have held many forums and activities, such as the Forum of Trade, Tourism and Investment Indonesia Vietnamese (TTI) held in June 2013 in Ho Chi Minh City. This forum created immediate opportunities for enterprises of the two countries to build partnerships in many areas. Mr. Herry Hotma, economist ambassador of the Republic of Indonesia in Vietnam has said: "We are making efforts through dissemination or relay information about the business opportunities in Vietnam to the Indonesian businessmen and vice versa. In addition, we always facilitates business contacts or trade contacts between the businessmen of both countries and we always bring the Indonesian businessmen to participate in trade fairs in Vietnam, either in Hanoi or Ho Chi Minh city, as well as in other provinces. And we also invite Vietnamese businessmen to participate in exhibitions in Indonesia3" First opened Indonesia-Vietnam political relations at the level of the consulate was on December 30, 1955. On August 10, 1965, Indonesia-Vietnam relations upgraded to the Embassy level, but after the events of the G-30 S / PKI, Vietnam recalled his ambassador from Jakarta, followed by Indonesia in 1973 the two countries sent back their respective ambassadors in Jakarta and Hanoi. Indonesia has opened representation at the level of the Consulate General in May 1993 in Ho Chi Minh City with the consent of the Government of Vietnam to improve bilateral relations with Indonesia. The good relations between these two countries in the political field concretely among others, are highlighted as follow : 
1. Rice aid awarded by Vietnam to Indonesia in 1986, while Vietnam was experienced a food shortage.

2. Vietnam support to Indonesia's election as Chairman of the Non-aligned Block.

3. Indonesia help for Vietnam in managing family planning programs, wisdom advices in the field of oil, investment, banking and transport.

4. Indonesian support to Vietnam wishes to sign the ASEAN Treaty of Amity and Cooperation.

5. Other Indonesian help to assist Vietnam in the form of program training and human resource development.

6. Various visits of the leaders and high officials of the two countries, culminating with the one of President Soeharto to Vietnam in November 1990 which was the first historic visit to Vietnam by a non-socialist leader to Hanoi since 1975.

7. The most crucial visitby of a vietnamese officer was the one of the Prime Minister Vo Van Kiet visit to Indonesiaon the 24th - October 27th $1991^{4}$

The basic Indonesia-Vietnam cooperation in the agricultural sector, ended up with an signature of a Memorandum of Understanding (MOU) in the agricultural sector on December 12, 1992 in Hanoi with an emphasis on:

1. The exchange of experts to enhance technology information and farming techniques.

2. Exchange of research outputs, training and comparative study

3. Joint ventures in the fields of production, processing and marketing for agricultural commodities.

The Vietnamese government declared his willingness to learn from Indonesia in the field of agricultural development in general and the science and technology of agriculture, livestock and shrimp aquaculture in particular, the Vietnamese government proposed to the Indonesian government to hold Counter Trade exchange, where the commodity offered by Vietnam rice, while the Indonesian government wanted Fertilizer.

\section{Economic Sector relationships}

The cooperation relation between Indonesia and Vietnam are based on the Agreement between the two governments regarding science and engineering were signed by Foreign Ministers of both countries on November 21, 1990, and has been renewed on 10 November 2001. The total trade between Indonesia and Vietnam in 2004 amounted to USD 664 million or a decrease of $16.3 \%$ compared to 2003. While the total trade in 2005 (January until July) USD 278.9 million, a relatively small decrease when compared to the same period in 2004.

The value of exports in 2004 was amounted to USD 360.6 million, an increase of $8.8 \%$ compared to 2003. The value of exports from January to July 2005 was amounted to USD 192.6 million or a decrease of $10.18 \%$ when compared to the same period 2004. The value of imports in 2004 reached USD 303.3 million, down $34.4 \%$ when compared to 2003 . The value of imports in 2005 (January-July) was amounted to \$ 86.2 million, 50.9\% decrease when compared to 2004. the main commodities export from Indonesia by Vietnam are textiles, chemicals, fertilizer, articles of base metal, paper products and plastic materials artificial resins, the main import commodities from Indonesia by Vietnam is crude oil, milled rice, processed foods, electrical appliance, sugar, fodder and textiles. Factors that threatened exports and imports between the two countries are:

1. Entry Barriers remain in effect for garment exports because of the imposition of quotas, At this time, the Vietnamese government is doing many efforts to abolish quotas. While the comparison between the guarantee of textile quotas through tenders continued to increase every year.

2. The perception of the majority of Indonesian businessmen still consider Vietnam as a country with less potential and doing business in Vietnam is very difficult.

3. Activity trade and distribution in Vietnam are only for local companies. Therefore 
each foreign company that will sell goods produced outside of Vietnam must hire a local distributor agent. In practice, foreign companies including Indonesian companies often have difficulty in selecting an agent that can be trusted.

4. Trade barriers against several major products, including a bunch on harmful products such as, among others, toxic chemicals, firearms, ammunition etc.

5. The Government of Vietnam is still maintain discretion that sets the seven commodity trade license from the Vietnamese Ministry of Trade, among others; fuel oil, glass, iron, cooking oil, sugar, motorcycles and four-wheeled vehicles with 9 seats chairs.

6. Indonesia must include a label on medicinal products exported to Vietnam.

Some of the agenda which will be conducted between 2004 to 2005, will boost the bilateral trade cooperation between the two countries as follows:

1. Session 3 Indonesia-Vietnam Joint Commission reported in the field of trade things that need to be followed in the Joint Commission Meeting 4th Bilateral trade is the increase becomes LISDI billion in the near future.

2. The bilateral meeting in the framework of the discussion for the approval of Banking Payment Arrangement (BPA) between Indonesia and Vietnam. In this regard, BNI bank designated as a bank of Indonesia need prior approval from Indonesia's central bank.

3. The meeting of the Joint Working Committee and the Joint Technical Working Group as the implementation of the Counter Trade MOU which was signed on 1 April 1999.

4. In the field of trade and investment, Vietnam and Indonesia always represent two potential and attractive markets. Indonesia with a population of approximately 240 million people is a potential market, at that time Vietnam is currently in the top of the road to become center of trade and investment. The Indonesian ambassador in Vietnam, Mayerf as said that: "Now, there are 30
Indonesian enterprises that are cooperating with Vietnam, and increasingly there are many other Indonesian business entities who want to find an opportunity to do business in Vietnam. The Indonesian government is also always pushing enterprises to enforce their cooperative relations with Vietnamese enterprises. Our orientation is to encourage Indonesia enterprises to seek cooperation partners in Vietnam, conduct mutually beneficial cooperation with Vietnamese enterprises so instead of investing $100 \%$ in Vietnam. From there, the economic free zones for the two countries could be developed together ${ }^{15}$.

\section{Business sector relationships}

The domestic market is quite large with a growing middle class that has an important role to enhance the industry and strengthen the purchasing power of consumer goods. The chamber of Commerce noted that the total trade last year between the two countries almost reached $\mathrm{Rp} 5$ billion. According to Suryo, this number could be much higher if it is reinforced by their business partnership potential. "The partnership can be improved not only in trade but also an investment to achieve maximum economic cooperation"6.

In Indonesia-Vietnam business forum, it was discussed the opportunities of cooperation and investments that involve a number of stateowned and private Indonesia enterprises that already invested in Vietnam such as those in the property and cement sector. Also present at the Business Forum, among others, Minister of Agriculture Suswono, State Enterprises Minister Dahlan Iskan and a number of corporate leaders and CEOs of private companies, such as Pertamina, Bank Mandiri, Kimia Farma, Semen Indonesia, Bulog, Dirgantara Indonesia, Bukit Asam, Ciputra Property, and Indofood SuksesMakmur, (EVA) took advantage of the Business Relationship To Enhance Trade and Investment Relations with Ho Chi Minh City in Vietnam. To further enhance bilateral trade relation, economic and investment relation 
between Indonesia and Vietnam, the Minister of Trade, Mari Elka Pangestu held a working visit to Ho Chi Minh City, Vietnam, on 23-25 April 2009.

In this business forum, the Minister of Trade provides exposition on the development of economic and investment policies in Indonesia. The minister explained about the bilateral relations between Indonesia and Vietnam during the period of 2008 and described some of the next steps to strengthen bilateral relations. At the end of his speech, the Minister of Trade of Indonesia in 2013 invited businessmen and investors Vietnam to do business and investments in Indonesia, as explained by the Minister of Trade, Indonesia is a fast and growing market and is part of the Asian market.

With the beginning of economic reforms and the entry of Vietnam as a member of ASEAN and WTO as well as the rising consumption of Vietnamese people, makes Vietnam a potential market for Indonesia products. In addition, the Vietnamese government policies that reduce trade barriers and the abolition of the quota system may also have a positive impact in improving Indonesia-Vietnam trade relations.

\section{Trade Sector Relationships}

The total trade between Indonesia and Vietnam in 2008 was amounted at US \$ 2.4 billion, an increase of $1.8 \%$ compared to 2007 with US \$ 2.3 billion. The trade grew on average over the period of 2004-2008 with a rate of $27.8 \%$. The trade balance between Indonesia and Vietnam over the last 5 years (2004-2008) shows a surplus position for Indonesia. In 2008 Indonesia surplus was 955.2 million US \$, an increase by $164.6 \%$ compared to 2007 with 361 million US \$. The rate of growth in the period 2004-2008 has a positive trade balance of $44.6 \%$.

Indonesia's exports to Vietnam in 2008 was amounted to US $\$ 1.7$ billion, an increase of 23.4\% compared with 2007 which was amounted to US \$ 1.4 billion (non-gas in 2008 amounted to US $\$ 1.7$ billion, an increase of
$23.5 \%$ compared to the same period in 2007 amounted to US $\$ 1.4$ billion). The rate of export growth on average over the period between $2004-2008$ was positive $31.5 \%$.

Indonesia's imports from Vietnam in 2008 was amounted to US \$ 717.7 million, down $27.8 \%$ compared to 2007 amounted to US \$ 994.2 million (non-oil in 2008 amounted to US \$ 567.9 million, decrease by $6.7 \%$ compared to 2007 amounted to 608.9 million). The rate of import growth on average over the period of 2004-2008 was $21 \%$ growing. Based on data from the General Department of Vietnam Customs, the total value of bilateral trade between Vietnam and Indonesia in 2014 in the sector of seafood products is up to 49.3 million US dollars, 71.91 percent more compared to 2013. Exports of Vietnam reached 5.3 billion dollars and Indonesian exports 43.9 million dollars.

In 2014, rice exports from Vietnam to Indonesia reached 327648 million tones (an increase of 170795 million tons compare to 2013) with a total carrying value of 150.6 million dollars (up to 64.93 percent). Just within the first four months of 2015, Vietnam exported seafood products to Indonesia at a value of 0.8 million dollars while exports of Indonesia was amounted to 8.9 million dollars. The total value during the first four months of 2015 decreased by 50.03 percent over the same period in 2014. During that period, rice exports from Vietnam reached 4.850 million tons (up 3.45 million tons) with a total value of 1.9 million dollars or 167.15 percent increase over the same period in $2014^{7}$. In the seafood business sector in particular, it was noticed a wide open opportunity for Vietnam interested in buying shrimp, seaweed, crabs and fish from Indonesia. Then the question was that: can Indonesia fulfill the needs of Vietnam regarding that field? It seems that Indonesia couldn't meet the demand because of various constraints. Economic, trade and investment between Vietnam and Indonesia if successfully can be a pilot project and have an impact to the region. It can help to create bilateral strategic partnerships between ASEAN members. In fact, partnerships that 
have been forged Indonesia and Vietnam to make a positive contribution to the improvement of relations and cooperation between the two neighboring countries and the dividends for the region.

\section{Conclusion}

Vietnam and Indonesia have formally raised bilateral relations since December 30, 1955. From that time until now, cooperation relations between Vietnam and Indonesia has never stopped growing, particularly the two countries have signed and improve that relationship into a strategic partnership in June 2013. Continuing these developments, in 2014 and then, Vietnam and Indonesia relations have continued to witness many positive developments, leading to the development of ASEAN community. As two major countries in Southeast Asia, Vietnam AND Indonesia relations have been progressing in many fields such as political, diplomatic, cultural, trade, investment and others. "Indonesia and Vietnam have a lot in common and can actually complement each other. Today, both Indonesia and Vietnam are building a stronger economy that is based on value-added industries ${ }^{8}$ said the Chairman of Kadin Indonesia, Suryo Bambang Sulisto, the Business Forum with the Vietnamese delegation led by its president, Truong Tan Sang, in Jakarta, on Friday ( 06.28.2013).

One among the important targets set by leaders of the two countries in 2015 is to intensify cultural exchange, helped bring the people of two countries closer. In addition to a series of retrieval program association, dissemination of culture and the arts that took place in Vietnam and Indonesia such as fairs culture in 2014, culinary weekend and others. Now the two countries are intensifying activities associate and socialize tourism to other countries. The ambassador Mayerf as said that with a population of 240 million, Indonesia will become a potential market for business entities for Vietnamese tourist companies. In 2014, the number of tourists from Vietnam increased dramatically compare with previous years. Ambassador Mayerfas added: "In the past, people usually choose Singapore Indonesia, Malaysia, and Thailand. But this is not manifested that Vietnam inferior to those countries because they do not know much about Vietnam, now knowing that Vietnam has a lot of very beautiful and natural scenery at a reasonable cost. The quality of services in Vietnam is very good and the Vietnamese people are very friendly, even better than in those named countries ".

\section{References}

[1]http://vovworld.vn/id-ID/Rumah ASEAN/Memperkuat-kerjasama-ekonomi perdagangan-dan-investasiVietnamIndonesia/173871.vov

[2]http://tapchitaichinh.vn/kinh-te-vi-mo/kinhte---dau-tu/dien-dan-thuong-mai-du-lichdau-tu-viet-nam-indonesia-26546.html

[3] http://vovworld.vn/id-ID/RumahASEAN/Memperkuat-kerjasama-ekonomiperdagangan-dan-investasiVietnamIndonesia/173871.vov

[4]http://vietkieu.vietnamplus.vn/ID/121/Cacchuyen-tham-cap-cao/Cac-chuyen-thamcua-lanh-dao-cap-cao-VietNamIndonesia/413.vnp

[5]http://vovworld.vn/id-id/Berita/Jumpa-perstentang-Pekan-Raya-PerdaganganIndonesia-dan-Forum-Bisnis-IndonesiaVN/390436.vov

[6]http://ekbis.sindonews.com/read/755186/34 /ri-vietnam-dorong-kerja-sama-dagangdan-investasi-1372414237

[7]http://baochinhphu.vn/Hoat-dong-Bonganh/Nang-kim-ngach-thuong-mai-VietNamIndonesia-len-10-ty-USD/196112.vgp

[8]http://economy.okezone.com/read/2013/06/ 28/20/829164/nilai-perdagangan-rivietnam-usd5-miliar

[9]http://vovworld.vn/id-ID/RumahASEAN/VietnamIndonesia-Hubungankemitraan-strategis-yang-mengarah-kemasa-depan/301603.vov 